Ensino, Saúde e Ambiente - V10 (2), pp. 79-106 Ago. 2017

\title{
COMO EDUCAR A IMAGINAÇÃO PARA COMPREENDER CIÊNCIAS? A PROPOSIÇÃO DO USO DE UM CONTO DE FICÇÃO CIENTÍFICA PARA OS ESTUDOS SOBRE CIÊNCIA E ARTE
}

\section{HOW TO EDUCATE IMAGINATION TO UNDERSTAND SCIENCES? THE PROPOSITION OF THE USE OF A LITERARY SCIENCE FICTION TALE FOR STUDIES ON SCIENCE AND ART}

\author{
Denise Figueira-Oliveira $^{1}$ e Giselle Rôças ${ }^{2}$ \\ ${ }^{1}$ Instituto Federal do Rio de Janeiro - Campus Nilópolis/Programa de Pós-Graduação Stricto Sensu em \\ Ensino de Ciências - PROPEC - do IFRJ/ denfioli@gmail.com \\ ${ }^{2}$ Instituto Federal do Rio de Janeiro - Campus Nilópolis/ Programa de Pós-Graduação Stricto Sensu em \\ Ensino de Ciências - PROPEC - do IFRJ/ giselle.rocas@ifrj.edu.br.
}

\begin{abstract}
RESUMO
Considerando a interdisciplinaridade ciência e arte como um movimento pedagógico para a divulgação científica, formação de professores e aprimoramento do ensino de ciências, o objetivo dessa investigação foi apresentar uma vivência desse movimento sob forma de oficinas, voltadas para o gênero ficção científica e observar sua aceitação em diferentes níveis do ensino. Participaram das oficinas alunos do ensino médio técnico em controle ambiental, da graduação, da especialização e do mestrado. Foram dinâmicas partilhadas nas oficinas, a comunicação oral, a socialização da palavra, a literatura e imagens temáticas. A metodologia, de abordagem qualitativa, foi inspirada na análise de conteúdo de obras de ficção científica de Piassi e Pietrocola. As oficinas funcionaram, como espaços de escuta sensível capaz de colher pensamentos imaginários dos alunos, quiçá concepções sobre outras formas de pensar a ciência ou constatar as diversas formas que ela está posta em nossa realidade social e como embasamento para o caminho metodológico a ser adotado por nós em trabalhos futuros.
\end{abstract}

Palavras-Chave: Ciência e Arte, Divulgação Científica, Ensino de Ciências, Ficção Científica, Educar o Imaginário.

\begin{abstract}
Considering the interdisciplinarity of science and art as a pedagogical motion for science communication, teacher training and improvement of science education, the objective of this research was to introduce an experience of this action in the form of workshops, oriented to science fiction genre and observe its acceptance at different levels of education. The workshops were attended by technical high school students in environmental control, graduation, specialization and master's degree. They were shared dynamics in the workshops, oral communication, debates, literature and thematic images. The methodology, with a qualitative approach, was inspired by the content analysis of Piassi and Pietrocola's science fiction researchers. The workshops behaved as spaces of sensitive listening capable of gathering imaginary thoughts of the students, perhaps conceptions about other ways of thinking about science or to verify the diverse forms that it is placed in our social reality and as a basis for the methodological path to be assumed by us in future works.
\end{abstract}

Keywords: Science and Art, Science Communication, Science Teaching, Science Fiction, Education of the Imaginary 


\section{Ensino, Saúde e Ambiente - V10 (2), pp. 79-106 Ago. 2017}

\section{Introdução}

As Ciências e as Artes têm se constituído como um lugar de trânsito livre para uma imaginação criativa de uma forma geral, um terreno fértil para descobertas, razão pela qual investimos esforços nessa interdisciplinaridade como estratégias do pensamento sobre as ciências, as artes e seus conceitos. Entendemos que a imaginação também é um campo que pode abrir novas perspectivas para identificar alternativas aos dilemas e impasses do mundo contemporâneo, dentre eles a carência de ideias ou a repetição das já existentes (GREENE,1995; BERNSTEIN, 2001).

Considerando a interdisciplinaridade existente entre Ciência e Arte como um movimento pedagógico para a divulgação científica, formação de professores e aprimoramento do ensino de ciências, o objetivo dessa investigação foi apresentar uma vivência desse movimento sob forma de oficina, voltada para o gênero ficção científica, além de observar sua aceitação em diferentes níveis do ensino.Caminhamos pelo terreno da educação do imaginário com objetivo da educação criativa como estímulo à renovação cognitiva necessária às inovações do nosso tempo.

$\mathrm{O}$ artigo ora apresentado baseia-se em uma pesquisa de abordagem qualitativa, com propósito exploratório, porque gostaríamos de experimentar a prática de "educação do imaginário" dos alunos por meio da literatura visando pesquisas futuras com mais dinâmicas envolvendo textos, imagens e jogos teatrais voltadas para ficção científica. Interpretamos o limite das fronteiras entre o real e imaginário com o conto literário escolhido, desenvolvendo as oficinas junto a um público com riqueza de diversidade e embasamentos distintos, a saber:alunos do ensino médio técnico do curso de controle ambiental, alunos da graduação em produção cultural, alunos da especialização em divulgação científica e aluno do mestrado em ensino de ciências. Em comum, todos têm a ciência muito presente nas discussões escolares cotidianas, pois são matriculados no Instituto Federal de Educação, Ciência e Tecnologia do Rio de Janeiro, localizado no munícipio de Nilópolis, Baixada Fluminense.

E como organizar a experiência de incluir a imaginação em sala de aula?

O estudo apresentado nesse artigo constituiu-se no acompanhamento sistemático de oficinas sobre ficção científica realizadas com alunos supracitados, alcançando um público final de 60 alunos no ano de 2016, conforme tabela abaixo: 
Ensino, Saúde e Ambiente - V10 (2), pp. 79-106 Ago. 2017

Tabela 1 - Distribuição dos alunos participantes das oficinas por nível e escolaridade.

\begin{tabular}{ll}
\hline Participantes das oficinas & Público \\
\hline $\begin{array}{l}\text { Ensino médio técnico do curso de } \\
\text { controle ambiental }\end{array}$ & 21 \\
Graduação em produção cultural & 9 \\
\hline Especialização em divulgação científica & 13 \\
Mestrado em ensino de ciências & 17 \\
\hline Fontes:autoras &
\end{tabular}

Foram dinâmicas partilhadas nas oficinas, a comunicação oral, a socialização da palavra, a literatura e imagens temáticas. As oficinas funcionaram, como espaços de escuta sensível capaz de colher pensamentos imaginários dos alunos, quiçá concepções sobre outras formas de pensar a ciência ou constatar as diversas formas que ela está posta em nossa realidade social e como embasamento para o caminho metodológico a ser adotado por nós em trabalhos futuros( FIGUEIRA-OLIVEIRA et al, 2012). A referida sistematização das oficinas se deu pelas seguintes etapas:

1) Socialização da fala - Osalunos foram convidados para um debate sobre a Ficção Científica antes e depois do contato com o conto literário e puderam apresentar suas visões a respeito do tema;

2) Comunicação Oral sobre Ficção Científica - Partilha do percurso histórico dessa temática, com material audio visual e projeção de imagens antigas e atuais;

3) Convite para a leitura de um conto de literatura brasileira de ficção científica ;

4) Entrega do conto literário Ah... Insensato Coração,

5) Introdução de uma situação- problema da oficina - Por meio de uma ficha avaliativa, solicitamos ao participante a intervir no conto, um exercício de criatividade, dar vazão a imaginação, ousando dar o passo seguinte ao final apresentado pelo autor.

6) Sessão impressões coletivas - Um debate semi-estruturado para ouvir a opinião dos participantes sobre o conto. Fazemos um outro convite para a leitura para o grupo do passo seguinte.

A análise do conto seguiu a proposta de Piassi e Pietrocola (2009), a qual será apresentada a seguir. No tocante ao material apresentado pelos alunos, foi realizada uma análise, usando como a utopia e distopia como as categorias iniciais. 


\section{Ensino, Saúde e Ambiente - V10 (2), pp. 79-106 Ago. 2017}

\section{Imaginação teórica: mais uma voz para o ensino de ciências}

Embora, reconhecer as potencialidades do imaginário no universo educacional não seja uma escolha nova (HUXLEY,1932; BRONOWSKI, 1983; GREENE,1995), entendemos que é um caminho que avança timidamente,sobretudo quando o cenário educacional é tão desfavorável como nos encontramos atualmente.

Robert e Michelle Root-Bernstein (2001) em um estudo diversificado sobre como escritores, pintores, músicos, cientistas desenvolvem sua imaginação, reforçam características que amparam nossa investigação quando afirmam que:

\footnotetext{
... em todos os campos, o pensamento criativo ocorre anteriormente à fala, antes que a lógica ou a lingüística entrem em cena, manifestandose em emoções, intuições, imagens e sensações corporais. As ideias resultantes só podem ser traduzidas em um ou mais sistemas formais de comunicação, como palavras, equações, pinturas, música ou dança depois que suas formas pré-lógicas já se desenvolveram o suficiente. Independente da infinidade de detalhes dos produtos dessa tradução (quadros, poemas, teorias, fórmulas e assim por diante), o processo que conduz a esse resultado é universal. Por isso, aprender a pensar criativamente numa área abre a porta para compreender o pensamento criativo em todas as outras (Robert e Michelle Root-Bernstein, 2001, Prefácio).
}

Se por um lado, há lacunas na compreensão da Ciência entre diferentes grupos de pessoas (WARD ET AL ,2010), se os meios e os objetivos da educação das ciências parecem não ser suficientes para engajar alunos para estudos científicos ou mesmo para compreender suas histórias de vida e seu mundo (FOUREZ,2003), se o estar em sala de aula para eles deixou de ser um desafio à curiosidade, ao pensamento sem qualquer vínculo entre conhecimento e produção de sentidos na realidade que o circundam, nós educadores estamos bem distantes do grande projeto educacional que é aprimorar a experiência pessoal e intelectual dos alunos e preparar competências para a vida (RODRIGUES, 2003).

Parece-nos claro que o ensino de ciências na sala de aula então, é o foco da observação de pesquisadores e por que não dizer, seu objeto de inquietação há mais de quarenta anos. Há diferenças consideráveis na experiência de ensino de ciências entre o Brasil e outros países do mundo, mas há também dilemas comuns entre os nossos modelos educacionais e os modelos de outras nações, o que parece produtivo considerarmos na discussão desse trabalho (FLEURY e MATOS, 1991; GARCIA, FAZIO e PANIZZON, 2011; VASSILIOU, 2012). Das reflexões de autores norte- 


\section{Ensino, Saúde e Ambiente - V10 (2), pp. 79-106 Ago. 2017}

americanos, tanto da educação,dentre eles, John Dewey e Peter Dow, quanto da ciência, Hunter Dupree e Dorothy Nelkin, podemos extrair que a Era Sputnik é como um marco para esse amplo movimento de reforma educacional capaz de ultrapassar suas fronteiras e ainda se encontrar em um processo contínuo nos dias de hoje na maioria dos países do mundo (ATKIN, 1997; BYBEE, 1997; DEBOER, 1997; DOW, 1997; RUTHERFORD, 1997). Segundo esses autores o contexto científico foi alterado substancialmente e a importância da ciência e suas aplicações precisam serem trazidas para o ensino de ciências na escola.

Considerando as diferenças de contexto, pesquisadores brasileiros também entendem que nesse fluxo de tentativas, embora nós tenhamos um considerável percurso de dedicação à temática ainda não atingimos as condições desejáveis entre o desenvolvimento da Ciência na prática escolar. Não a ponto de, colocarmos o processo que envolve o ensino e a aprendizagem em sintonia com o que acontece na vigente cultura-mundo que abrange, a Ciência, a Tecnologia e a Sociedade (KRASILCHIK, 2000; CASTRO, 2015). Assim, a necessidade de uma renovação da instância cognitiva impulsiona novos esforços para alcançar esse objetivo.

Dentre as diversas perspectivas conhecidas destacamos três que nos parecem relevantes. A primeira é a vertente que busca problematizar a história e a filosofia das ciências incluindo as controvérsias e rupturas epistemológicas no sentido de, aproximar os conteúdos científicos associados a seu significado histórico, mostrar a nãolinearidade, os obstáculos e pistas falsas das ciências, bem como relacioná-las com propósitos éticos, culturais e mesmo econômicos da realidade social dos aprendizes (CARNEIRO e GASTAL, 2005). Matthews (1995) defende que, as disciplinas científicas embasadas pela história e filosofia das ciências têm mais condições de contribuir para conhecimento integral da ciência pelos aprendizes e para o aprimoramento dos professores, sobretudo: auxiliando odesenvolvimento de uma epistemologia da ciência mais rica e mais autêntica, ou seja de uma maior compreensão da estrutura das ciências bem como do espaço que ocupam no sistema intelectual das coisas (MATTHEWS, 1995, p.165).

A segunda vertente a ser destacada, por razões pedagógicas e sociais, investe na ação da inteligência e da imaginação, ou seja, no pensamento criativo. Destacamos, nesse breve estudo exploratório pelo diálogo entre Ciência e Arte,um entendimento de 


\section{Ensino, Saúde e Ambiente - V10 (2), pp. 79-106 Ago. 2017}

que essa é chave de renovação cognitiva de professores e aprendizes, capaz de dar forma às inovações da sociedade futura em todas as áreas.

Tais vertentes constatam a inadequação da fragmentação entre as disciplinas diante de realidades sociais multidisciplinares ao nosso redor. A abordagem do pensamento criativo é portanto, integradora, visa compor um novo tecido social que entrelace as intuições e os intelectos, para permitir uma melhor compreensão de conceitos, conteúdos diversificados e contextualizados pela consideração da cultura dos indivíduos.

Optamos por esta vertente nesse estudo como proposta de uma avaliação diferenciada na área de Ciências, sem, no entanto, ignorar a vertente de Georges Snyders, sobre a satisfação que a escola precisa dar aos alunos.

Snyders em Alegria na Escola (1993), A escola como a vida, a vida como “escola"(2001) traz à luz a perspectiva da alegria, do prazer ao ter contato com o conhecimento, ao contemplar explicações que façam sentido e sensibilize os alunos para o cotidiano do qual fazemos parte. Bauman (2013), compreende que tal realidade "modernidade líquida", ou seja, nenhuma das formas consecutivas de vida social é capaz de se manter constante.

E como lidar com o conhecimento científico tão presente nas práticas e relações sociais após essa constatação não só de dinamismo do nosso tempo, mas também da descartabilidade ou liquidez?

Como o ensino de ciências poderá fazer frente a essa realidade? Quais seriam as estratégias?

Diante de impasses assim, fomos impulsionados a lidar com a característica natural dos seres humanos: criar. Foi assim que desde os primórdios, os seres buscaram saída para superar a fome, a solidão e a ignorância, criando, buscando saídas.

Vale destacar a crítica apontada por Snyders (1993) sobre a "recusa escolar". Para o autor esse não engajamento por parte dos alunos, considerada por alguns professores como um capricho, possui algum significado que precisa ser reinterpretado. O referido autor foi defensor da renovação da escola a partir do viés da recuperação da alegria no aprender, no descobrir, já que a escola segundo seus estudos tornou-seuma instituição desmotivadora. Isso porque de acordo com seus estudos, tendo o século VII como marco histórico, os valores educativos sempre foram colocados ao excessivo rigor e austeridade. Ciente que a questão da alegria e a não-alegria encontraria muita 


\title{
Ensino, Saúde e Ambiente - V10 (2), pp. 79-106 Ago. 2017
}

resistência no tema relevante na educação,Snyders apresenta trechos ilustrativos desse lugar de temor e castigo que era a escola, dito por dois grandes escritores conhecidos, sujeitos de sua pesquisa, a saber:

\begin{abstract}
Seus mestres sempre pareceram considerar que a satisfação que podia haver em aprender isto ou aquilo era uma coisa com a qual [o aluno] não tinha nada a ver. Butler(1921 apud Snyders, 1993);dar-lhes tudo de que não gostavam, e absolutamente nada do que gastavam(...) fazer tudo o que lhes desagradava, sem nunca fazer o que lhes era agradável.Dickens (1864 apud Snyders, 1993).
\end{abstract}

A riqueza da tese de Snyders emerge, portanto, pela busca de emoções vividas e retratadas no meio literário, onde autores falam de si mesmos ou criam outras vidas e obras, não necessariamente incondicionais para a escola, e sim com "perfumes imaginários" que podem ser bastante atraentes, estabelecendo pontes entre o saber ensinado e a cultura vigente. E afinal, o que queremos não é atrair os alunos para a escola? Não queremos tornar o que ensinamos mais interessante para a comunidade escolar?

Bronowski (1983), Read (2001) e Pietrocola (2004), estudiosos da contemporaneidade também procuram entender a falta de prazer dos alunos com as ciências e sugerem a relação com as Artes, como narrativa de mundo, uma alternativa didático-pedagógica mais adequada de produzir ideias e organizá-las.

Nessa direção, após pesquisa realizada (FIGUEIRA-OLIVEIRA, 2012) apresentamos uma proposta para "educar o imaginário", promovendo uma maior aproximação dos alunos com as ciências, por meio de uma oficina cujo tema é ficção científica (FC). A escolha interdisciplinar para a abertura de outros horizontes e olhares para o campo científico e o ensino de ciências, foi a interface entre Ciência e Arte. Assim, apresentar e debater conteúdos da FC (comunicação oral, socialização da fala, texto literário e imagens) como base para deflagrar a imaginação dos participantes sobre as ciências foi o nosso objetivo nesse estudo.

\section{Um conto, um ponto: a ficção científica (FC) educando a imaginação sobre a ciência em sala de aula}

Este estudo trata da introdução de um conto literário de ficção científica brasileira, como recurso inovador,bem como uma proposta de interdisciplinaridade entre Ciência e Arte em aulas de Ciências. Essa etapa do estudo teve como preocupação central avaliar a qualidade pedagógica implícita no referido conto literário -“Ah... 


\section{Ensino, Saúde e Ambiente - V10 (2), pp. 79-106 Ago. 2017}

Insensato Coração", de João Vaz (2009), a fim de incluí-lo no conjunto de atividades de um movimento que promove o diálogo dessas duas narrativas do conhecimento no ensino de ciências.

Na perspectiva de autores como Piassi e Pietrocola (2007, introdução):

...mais do que um recurso didático adicional, a ficção científica deveria ser encarada como um discurso social sobre as ciências que expressa questões, interesses e preocupações atuais a respeito do desenvolvimento científico e tecnológico.

Entendemos que essa relação estratégica com conhecimento aponta para objetivos gerais como, divulgar as ciências, tornar as aulas de ciências mais instigantes e alegres, incluir novos elementos na estrutura conceitual dos alunos, bem como ativar a capacidade imaginária e criativa desse público. Considerando que, a partilha de conto de ficção científica deve ser mediada por uma metodologia de análise, o professor ganha chances de ampliar seu repertório cultural nessa abordagem, primeiramente somando a seus saberes as novas competências relativas à literatura de FC, e concomitante a isso, promovendo a habilidade da leitura e interpretação, tornando-se um subsídio para a aprendizagem de qualquer disciplina, já que abriga a possibilidade de alargar o horizonte crítico-reflexivo de quem lê.

Eis que o conto abriga potencialidades que tornaram sua escolha mais próxima de nosso objetivo pedagógico: uma narrativa curta, as ideias são definidas e potentes, além de ser um convite a um mergulho em uma história. Em sua estrutura conceitual, um universo inteiro é criado sob um estilo sucinto, e ainda assim, capaz de problematizar a realidade social na velocidade das mudanças que estão em curso.

Segundo Décio (1977, p.46) um conto pode ser entendido como:

.... forma dramática reduzida no tempo e no espaço, para configurar um acidente, ou um incidente, enfim um acontecimento na vida de uma personagem. Ora, se o conto se preocupa com apenas um fato, deriva daí a presença de uma única ação. Daí haver unidade de ação no conto. Tudoportanto deve convergir para a elaboração de um problema, limitado no tempo e no espaço.

Como um tipo de obra concisa, o conto é também compatível um lugar "líquido" da identidade contemporânea, propositalmente moldado para atender a expectativas do leitor que procura esse gênero (SIMON, 2007). O que para aos incautos pode parecer que os contos são recortes de histórias completas, convém elucidar e ressaltar que, no conto o lugar da significação não é perdido, tal como poderia haver com recortes ou resumos. 
Cortázar (1993,p.151-152), escritor cujo um dos traços característicos é deambular por estratos múltiplos da realidade e o entrecruzamento de gêneros, destacase no rigor ao conceito de Conto Literário,teoriza sobre a possível incorreção de similaridade literária entre o recorte e o conto desenvolvendo a seguinte diferenciação:

... o fotógrafo ou o contista sentem necessidade de escolher e limitar uma imagem ou um acontecimento que sejam significativos, que não só valham por si mesmos, mas também sejam capazes de atuar no espectador ou no leitor como uma espécie de abertura, de fermento que projete a inteligência e a sensibilidade em direção a algo que vai muito além do argumento visual ou literário contido na foto ou no conto.

\section{A ficção científica (FC) nesse estudo exploratório}

Com planos de diversificar as estratégias pedagógicas, com a proposição de um modelo de comunicação entre Ciência e Arte, escolhemos nesse exploratório o caminho literário para futuras incursões. Embora este estudo encontre pares com práticas teóricas comuns, entrecruza a experiência particular dos grupos pesquisados (alunos do ensino médio, graduação, especialização e mestrado) delimitando um campo próprio.As diferentes contribuições teóricas permitem que a pesquisa adquira faces plurais enriquecendo o percurso.

Buscamos o apoio teórico inicial nas ideias de Piassi e Pietrocola (2007, 2009), estudiosos que há muito se debruçam sobre a consolidação da análise sobre a relação entre a ficção científica e o ensino de ciências. Especialistas em mediar o discurso sobre a ciência tanto com o cinema quanto a literatura desenvolveram uma metodologia de categorização do olhar sobre essas obras.

Pelo que vimos e ouvimos nas etapas de socialização da fala sobre FC com os alunos é que, não obstante o apego a outras linguagens tecnológicas e redes sociais, esses dois meios culturais de expressão humana parecem ocupar um lugar cativo no universo sensório deles, sobretudo o cinema, linguagem até então mais explorada no ensino de ciências.

Visionários, Julio Verne e Herbert George Wells, no final do século XIX, imersos nas mudanças tecnocientíficas de suas histórias, ao criarem obras de ficção pensavam em atrair os leitores com fantasias e com entusiasmo para crítica social, respectivamente.

Nesse sentido, artista e cientista têm diferentes apreensões do real e somente o cientista tem o compromisso de ser mais fiel à ela. A contribuição do artista existe, sem 


\section{Ensino, Saúde e Ambiente - V10 (2), pp. 79-106 Ago. 2017}

dúvida, no que sua arte pode criar de discernimento, mesmo que este se encontre diametralmente oposto aquilo que retrata a obra. O compromisso não é com o literal e sim com o que a obra provoca nos indivíduos, em suas ressignificações.

A análise de conteúdo proposta por Piassi e Pietrocola (2009), guarda características que tendem a valorizar os termos didáticos, já que saber como o indivíduo aprende parece ser tão complexo quanto às dificuldades em compreender a construção social da ciência. Os referidos autores chamam a atenção para o fato de que o autor da obra cinematográfica ou literária, não necessariamente a compõe com base em leis científicas, e sim, buscando uma estratégia narrativa que faça sentido para ele, que seja fundamental para atingir esse ou aquele efeito.

No caso do ensino de ciências, o trabalho com filmes e literatura de ficção científica implica em atentar para a expressão verbal dos alunos sobre as situações e fenômenos científicos possíveis, favorecendo um diálogo crítico. É a partir do que emerge como erro para a ciência, que o professor ou mediador pode aproveitar para promover um ensino instigante e elucidativo, a fim de obter em algum tempo, alguma aprendizagem mediante arranjos e desarranjos epistemológicos.

Assim, nos parece, ao trabalharmos sob essa vertente que teremos a ficção científica como mais que uma simples estratégia para tornar a aula mais interessante. Tanto na ciência quanto na arte a proposta é de um engajamento reflexivo.Nas palavras do poeta Ferreira Gullar (2015): a arte existe porque a vida não basta. Segundo Asimov (1984), a capacidade de ir além, de extrapolar tudo, está nos seres humanos; felizmente, razão pela qual cuidar do aprimoramento dessa imaginação é uma questão posta para o universo das ideias.Desta feita, o nosso meio social é a fonte de toda a inspiração para ficção científica.

Os autores Piassi e Pietrocola (2009) trazem por meio de seus levantamentos sobre o tema da FC, a questão apontada por Rabkin: "o que é importante na definição de ficção científica não são as justaposições de armas de raios e aventais de laboratórios, mas os hábitos mentais "científicos"(RABKIN, 1977, p-120-121 apud PIASSI e PIETROCOLA, 2009, p. 528).

Os hábitos mentais nos importam e permeiam também a nossa proposta de pesquisa para o ensino de ciências, provocando a racionalidade científica da ficção com a intenção de mexer com a opinião do outro, tirá-lo da zona de conforto. O 


\section{Ensino, Saúde e Ambiente - V10 (2), pp. 79-106 Ago. 2017}

desafio?Quando ele for para o outro lugar, sua bagagem sobre os conteúdos científicos devem ajudá-lo a pensar melhor o mundo em que vive.

Eis que a sedução perpassa a instância sensória, onde figuram as angústias, o espanto, o encanto, sobretudo o campo afetivo.Tendo como base, a própria afirmação dos autores de que as categorias são expansivas e não exaustivas, buscamos aproximar o contoAh... Insensato Coração, da metodologia de análise de conteúdo proposta por Piassi e Pietrocola (2009). Essa análise do conto também foi um resultado nossa pesquisa.

Os referidos autores criaram categorias de elementos contrafactuais (especulação hipotética ou contra os fatos) para sistematizar a produção do discurso ficcional seja no cinema, ou na literatura. Tal suporte teórico-metodológico ilumina a nossa análise no sentido de tratar o conteúdo do conto literário selecionado por nós, visando desdobramentos (ganchos, interrogações, provocações, pistas) para o ensino de ciências. Observemos o quadro 1, retratando as categorias criadas abaixo:

\section{Quadro 1: Categorias expansivas de elementos contrafactuais (CEC)}

\begin{tabular}{|c|c|}
\hline CIENTÍFICO & Elemento contrafactual que é (ou não) construído por associação ao discurso científico. [...] \\
\hline SOBRENATURAL & $\begin{array}{l}\text { Elemento contrafactual que tenha (ou não) implícito em sua construção origens não } \\
\text { cognosciveis de acordo com pensamento lógico causal típico da ciência, tais como a magia, a } \\
\text { mitologia e a religião. [...] }\end{array}$ \\
\hline REAL & $\begin{array}{l}\text { Atribuição ( ou não) ao elemento contrafactual, de um caráter de realidade presente, de } \\
\text { existência real e constatável no mundo empírico do autor e de seu "leitor implícito", entendido } \\
\text { aqui como define Todorov(2004). [...] }\end{array}$ \\
\hline EXTRAORDINÁRIO & $\begin{array}{l}\text { Elemento contrafactual construído e considerado ( ou não) como extraordinário em relação à } \\
\text { percepção do leitor implícito. [...] }\end{array}$ \\
\hline INUSITADO & $\begin{array}{l}\text { Elemento contrafactual construído e considerado ( ou não) como extraordinário na percepção } \\
\text { do personagens. [...] }\end{array}$ \\
\hline POSSÍVEL & $\begin{array}{l}\text { Elemento contrafactual assumido ( ou não) pelo discurso da obra, como possível, de acordo } \\
\text { com o conhecimento científico presente. }[\ldots]\end{array}$ \\
\hline EXPLICADO & $\begin{array}{l}\text { Elementos contrafactuais para os quais a narrativa constrói ( ou não) um contexto explicativo } \\
\text { por meio de uma rede de relações ou formando um encadeamento lógico a partir de } \\
\text { premissas assumidas como científicas. [...] }\end{array}$ \\
\hline CONCEITUAL & $\begin{array}{l}\text { Elementos contrafactuais construídos (ou não) a partir de conceitos científicos, remetendo a } \\
\text { concepções bem delimitadas e assumidas como de conhecimento do leitor implícito. [...] }\end{array}$ \\
\hline CONEXO & $\begin{array}{l}\text { Elementos contrafactuais apresentados ( ou não) em uma continuidade lógica construída } \\
\text { como o mundo ficcional. [...] }\end{array}$ \\
\hline
\end{tabular}

Fonte: Piassi e Pietrocola, 2009.

\section{Cada conto um ponto: a análise do conto "Ah... Insensato Coração"}

O conto literário apresenta uma sociedade hipotética controlada pelo gênero feminino e o foco principal da história se passa em um Parque de Espécies Extintas, onde está isolado em uma jaula, separado dos demais frequentadores, o último exemplar 


\section{Ensino, Saúde e Ambiente - V10 (2), pp. 79-106 Ago. 2017}

da espécie humana. O principal conflito se dá na relação de Eva Maria, funcionária do Parque, que desde a infância observa, sem travar relações, com o referido exemplar do gênero masculino. O conflito emerge no conto quando o fechamento do Parque é cogitado, em função do baixo número de visitantes.

Em um dos mais marcantes momentos do conto "Ah... Insensato Coração", de João Vaz (2011, p. 211), encontramos o seguinte trecho:

...Eva encontra o homem sentado na varanda, como sempre faz àquela hora, indiferente à mudança, indiferente a tudo. Sente pena dele, da sua solidão enorme de exemplar único de uma espécie em que só um dos gêneros sobreviveu.

No início, o Parque mantinha três - um jovem, um adulto e um velho-, mas pararam de clonar reposições, e ele agora sozinho há oito anos. $\mathrm{O}$ último.

Com exceção da ligeira protuberância do abdome, o tronco quase não tem curvas. Essa monotonia de linhas retas e o crânio mal coberto pelos cabelos ralos dão ao corpo uma aparência frágil...

Embora o narrador do texto literário não se mostre, ele é observador e não personagem, a natureza de sua autoria não pode ser desconsiderada, já que optamos por avaliar a obra em sua totalidade visível. Suscita a curiosidade o fato dele, ser do gênero masculino, e, ao longo do texto descrever o estado de fragilidade da espécie humana nas condições criadas para esse gênero. Na posição de leitores, somos convidados a essa condição mental intrigante em que ele constrói o conto, sua metáfora, sua crítica à ciência, ao autoritarismo, a sociedade imaginada. É possível notar também que há alguma preocupação do autor em mencionar fatos científicos, bem como situá-los em um tempo e espaço, nos quais, a ciência atingiu uma supremacia que acaba marginalizando o convívio ou relegando-o à uma instância virtual.

Habituados no momento presente com parques científicos que enfatizam espaços oferecidos para educação ambiental, cultural e patrimonial, com objetivos de integração, os leitores do conto experimentam o oposto: a ameaça de extinção dessas possibilidades. Eis o principal elemento do conto, o conflito.

Também descrita como extrapolação, outro elemento encontrado, é uma das características da ficção científica (LE GUIN, 2014), pode ser percebida no conto literário partilhado com o público dessa pesquisa, nas oficinas de FC. O autor conduz sob essa base, de forma intensa e até dramática, sua imaginação, conjecturas sobre as ciências, sobretudo a tecnologia, já que descreve uma biologia alternativa, suscitando o debate sobre o impacto da ciência na sociedade. 


\section{Ensino, Saúde e Ambiente - V10 (2), pp. 79-106 Ago. 2017}

Outra característica corrente dos autores de ficção científica é o ofício de mentir. Os autores criam os personagens, os lugares, os fatos, o tempo, o espaço, onde suas histórias transcorrerão. Le Guin (2008, p.11) menciona que "verdade é uma questão de imaginação" e Gotlib (2004) se refere a "critérios de invenção". Nesse percurso de, dar vazão à imaginação, desejar mudar a realidade, imprimir emoção, escolhem um caminho peculiar, nem sempre direto, para apresentar suas "verdades", suas histórias fictícias (LE GUIN, 2008). Este grau de complexidade temática em obras de ficção tornou capital o tipo de avaliação de seus conteúdos, pois estão dispostas nessas obras ideias, valores, e importantes variáveis que fazem parte da estrutura ficcional do autor.

Vale ressaltar os diversos estudos exitosos na última década sobre uso de ficção científica para o ensino de ciências (ZANETIC,1989; PIASSI 2007; FERREIRA, 2013; CAMILO, 2014) o que justifica cada vez mais as fundamentações teóricas para essa prática interdisciplinar.

\section{Contando em categorias expansivas contrafactuais}

Eva Maria, único personagem nomeado no conto dessa sociedade alternativa, com a biologia alternativa, nos remete a categoria sobrenatural, no que tange ao que parece tomar como referência a Eva. Embora tenha origem no hebraico Hawwá, Havah, que deriva da raiz hawá, cujo significado é "ela viveu”, Eva parece abrigar a intenção do autor, associar o nome à personagem bíblica relatada no livro Gênesis, no Antigo Testamento, portanto, um elemento contrafactual que tem implícito a religião. Essa versão também é passível de consideração porque o nome Eva, nesse sentido representa na sociedade cristã a primeira mulher da humanidade segundo a religião católica, onde Eva foi criada por Deus a partir da costela de Adão.E,Maria, considerada sua primeira mulher, adepta do cristianismo.Essa consideração chama a atenção em um texto onde a espécie humana se reduz ao último homem que vive enjaulado no Parque das Espécies Extintas.

Um banco de DNA capaz de clonar plantas e animais, código genético, aquecimento global, pesquisa, grandes epidemias, armas atômicas; enfim, o avanço da tecnologia, são temas abordados no conto que lhe conferem a categoria de 


\section{Ensino, Saúde e Ambiente - V10 (2), pp. 79-106 Ago. 2017}

[+científico] ${ }^{1}$ (PIASSI e PIETROCOLA, 2009). Aliás, os argumentos científicos presentes no texto foram pistas para o aproveitamento didático nessa pesquisa.

Outra prova fecunda da literatura é a análise de Barthes em seu clássico, Aula (1977, p. 90) quando afirmou:

...Se, por e não sei que excesso de socialismo ou e barbárie, todas as nossas disciplinas devessem ser expulsas do ensino, exceto uma, é a disciplina literária que devia ser salva, pois todas as ciências estão presentes no monumento literário...

Eva Maria vive em uma sociedade com predomínio absoluto do gênero feminino e tem mais mães do que em uma sociedade tradicional/real, trabalha no Parque com uma profissão comum e factível aos olhos dos leitores. Dessa forma, o conjunto se encaixaria na categoria [-possível], mas o é apenas em parte pelas mínimas condições reais dos jogos narrativos que permeiam os contos de ficção científica em uma combinação de argumentos sustentados na obra. Le Guin (2014) atenua o que poderia parecer estranho, dizendo que: escritores podem usar todo tipo de fatos para sustentar sua coleção de mentiras.A categoria [-real] acena com uma espécie de narrativa próxima do real, em alguma instância desse tipo de obra, como mostra o seguinte trecho (VAZ, 2011, p.212):

...quando começou a trabalhar no parque Eva tentou melhorar a qualidade do material audiovisual passado na residência dos homens. Entremeou à música de relaxamento algumas peças clássicas e, às paisagens projetadas nas paredes, cenas de documentários sobre peixes e plantas...

No conto em questão, Eva Maria encontrava-se em um dilema, acreditar nas informações que ela herdou de sua família - a genética humana contém um ímpeto destrutivo programado - ou dar vazão a compaixão que tem pelo último homem daquela sociedade?Sociedade em que a mulher nem de longe, ocupa o papel de vítima oupassível de dominação. Nesse sentido, o conto parece incorporar, além de uma inovação, uma referência a um sistema de justiça inverso ao que presenciamos no mundo fora da ficção.

Fato é que, a compreensão sobre a opressão sofrida pelas mulheres no sistema patriarcal é um debate feminista nacional e internacional. Já no conto, a assertividade

\footnotetext{
${ }^{1}$ Pietrocola e Piassi (2009) indicam o uso dos sinais - e + para reforçar quando uma das categorias está mais ausente ou presente.
} 


\section{Ensino, Saúde e Ambiente - V10 (2), pp. 79-106 Ago. 2017}

das "mães" de Eva Maria em mantê-la longe de qualquer contato com a espécie humana revela uma postura radical e autoritária, talvez uma crítica velada do autor. Embora haja a estrutura de dominação invertida, o homem não ter direito sequer a sua identidade histórica, qual seria a ideia do autor? Dar o papel de vítima ao homem? Inverter na ficção a ordem que tem regido as sociedades humanas?

A espécie humana representada por ele no texto, isso aparece como tácito, parece ter comprovado ao longo da história só ser capaz de destruir seu meio ambiente.Eis que emergem nessa visão, pistas e pontes a partir das quais o mediador ou professor de Ciências pode problematizar as visões que julgar necessárias, formular pressupostos, ampliar as formas de buscar informações a respeito e diversificar as discussões sobre os conceitos científicos em sala de aula.

O uso didático do conto literário escolhido por nós visou o encadeamento de ideias, de elementos, conceitos da ciência e da sociedade que pudessem ser mobilizados. Piassi e Pietrocola (2009) ao esmiuçarem os diferentes traços distintivos dos contos ou filmes de FC, chegam a um plano geral destacado no quadro 2 abaixo:

Quadro 2: Categorias dos diferentes traços distintivos. Os sinais positivos e negativos, reforçam a ideia de presença ou ausência das características apontadas.

\begin{tabular}{|c|c|}
\hline $\begin{array}{l}\text { Emulativos: } \\
{[+ \text { científico][+real][+possivel] }} \\
{[+ \text { conexo][-sobrenatural]][-inusitado] }}\end{array}$ & $\begin{array}{l}\text { Consideramos emulativos elementos que reproduzem de } \\
\text { forma mais ou menos fiel o que é considerado como existente } \\
\text { no mundo real. }\end{array}$ \\
\hline $\begin{array}{l}\text { Extrapolativos: } \\
{[+ \text { cientifico][+extraordinário][+possivel][ }} \\
\text { +conexo][-sobrenatural][-real] }\end{array}$ & $\begin{array}{l}\text { Para Allen(1976) são extrapolativas as histórias "que tomam o } \\
\text { conhecimento corrente de uma das ciências e projetam } \\
\text { logicamente quais podem ser os próximos passos nessa } \\
\text { ciência"(p.22). [...] }\end{array}$ \\
\hline $\begin{array}{l}\text { Especulativos: } \\
{[+ \text { científico][+extraordinário][+explicado][+conexo][- }} \\
\text { sobrenatural][-real][-possivel] }\end{array}$ & $\begin{array}{l}\text { Allen (19760 chama de especulativas histórias que imaginam } \\
\text { um futuro mais remoto que as extrapolativas, mas que, apesar } \\
\text { da inerente dificuldade desse processo, retratam ciências } \\
\text { "semelhantes às ciências que conhecemos agora e }[\ldots] \text { nelas } \\
\text { baseadas"(p.22) [...] }\end{array}$ \\
\hline $\begin{array}{l}\text { Anômalos: } \\
\text { [+científico][+extraordinário][+inusitado][- } \\
\text { sobrenatural][-real][-conexo] }\end{array}$ & $\begin{array}{l}\text { Denominados anômalos elementos que são construídos por } \\
\text { ruptura explícita com o conhecido. [...] }\end{array}$ \\
\hline $\begin{array}{l}\text { Associativos: } \\
{[\text { [+científico][+extraordinário][+conceitual][+conexo][- }} \\
\text { sobrenatural][-real][-possivel][-explicado] }\end{array}$ & $\begin{array}{l}\text { Um processo de construção contrafctual é a associação } \\
\text { semântica de ideias conhecidas, produzindo um efeito de } \\
\text { conjetura sobre possibilidades. [...] }\end{array}$ \\
\hline $\begin{array}{l}\text { Apelativos: } \\
\text { [+científico][-extraordinário][+conexo][- } \\
\text { sobrenatural][-real][-possível][-explicado][-conceitual] }\end{array}$ & $\begin{array}{l}\text { Em muitos casos, a história estabelece não mais que uma vaga } \\
\text { conexão ou menção a uma possivel justificativa científica dos } \\
\text { predicados alternativos } .[\ldots]\end{array}$ \\
\hline $\begin{array}{l}\text { Metonímicos: } \\
\text { [+científico][+extraordinário][-sobrenatural][-real][- } \\
\text { possível[-explicado][-conceitual][-conexo] }\end{array}$ & $\begin{array}{l}\text { É comum, nas obras de FC tentar-se atribuir um ar científico a } \\
\text { elementos da história como uma das estratégias de construção } \\
\text { da verossimilhança. [...] }\end{array}$ \\
\hline $\begin{array}{l}\text { Inalterados: } \\
\text { [+científico][-sobrenatural][-real][-extraordinário][- } \\
\text { possível][-explicado][-conceitual][-conexo] }\end{array}$ & $\begin{array}{l}\text { Feixes laser visíveis no vácuo do espaço, gravidade no interior } \\
\text { das espaçonaves, são muito numerosos os "erros" cometidos } \\
\text { pelos roteiristas. [...] }\end{array}$ \\
\hline
\end{tabular}

Fonte :Piassi e Pietrocola (2009)

Com base nas categorias apresentadas no quadro acima, o conto "Ah Insensato Coração" pertence a categoria especulativa, pois ele é [-real], [-possível], [+científico], 


\section{Ensino, Saúde e Ambiente - V10 (2), pp. 79-106 Ago. 2017}

[+extraordinário] ao se tratar de uma sociedade exclusivamente formada com seres do gênero feminino, na qual os homens são apresentados como objetos de observação em extinção.Entretanto, o conto apresenta outro caminho possível aos leitores, já que incluir questões controversas enriquece as vivências em sala de aula e abre espaço para a criatividadedos alunos.

Apoiadas nas observações do início da pesquisa, nas características contextuais de cada turma (EM, G, E e M $)^{2}$, onde a oficina de FC foi desenvolvida,a pesquisa ganhou outras nuances, a ponto de podermos avançar e reconhecermos outras perspectivas. O quadro 3 é adicionado a experiência vivida em nosso estudo, com a proposição de uma nova categoria:

\section{Quadro 3: material empírico}

\begin{tabular}{|l|l|}
\hline $\begin{array}{l}\text { Categoria Emergente da } \\
\text { Pesquisa }\end{array}$ & $\begin{array}{l}\text { [+explicado][+conceitual][+afetivo][-real] } \\
\text { [-extraordinário][-possível][-conexo] }\end{array}$ \\
\hline & Fonte: autoras
\end{tabular}

Um outro elemento pode ser acrescido à categoria, o afeto. Tal instância sensória emergiu das falas e escritos dos participantes, a ser descrita posteriormente, bem como da aparente indução no título do conto. Afora o interesse e disposição para um tema, devido ao fato deste ser mais ou menos atraente, há possibilidades de trazermos para as atividades didáticas um pouco do inusitado, do alegre, do afetivo, tal qual preconizava Snyders (1993).

É possível notar na leitura do conto, a questão afetiva na compaixão de Eva Maria pelo único exemplar da espécie humana, desde que era uma menina até, mais tarde quando já adulta resolve entrar na jaula, ou mesmo ser movida pela incerteza de que as informações que ela tinha sobre aquele ser humano condiziam com a verdade. $\mathrm{O}$ conto inclui um lugar para o afeto, para a subjetividade, para uma instância do conhecimento onde sempre existiu em demasia a lógica-racional em detrimento da consideração dos afetos no processo epistemológico.

O conto literário de ficção científica como toda forma de narrativa visa uma comunicação com o outro, e é uma nova incursão das autoras que já trabalharam na interface entre Ciência e Arte com teatro, cinema, quadrinhos, música e artes plásticas

\footnotetext{
${ }^{2} \mathrm{EMT}=$ ensino médio técnico; $\mathrm{G}$ = graduação; $\mathrm{E}$ = especialização; $\mathrm{M}=$ mestrado
} 


\section{Ensino, Saúde e Ambiente - V10 (2), pp. 79-106 Ago. 2017}

(FIGUEIRA-OLIVEIRA ET AL, 2012; NASCIMENTO e RÔÇAS, 2016) tendo em vista um ensino mais criativo.

\section{Dando asas à imaginação: a Ciência e a Arte no ensino de ciências}

De Masi é um dos pensadores que mais se envolveu com estudo da criatividade no último século. O autor (1991) estudou de forma singular esse fenômeno tipicamente humano em suas inquietações quanto à relação natureza e cultura, seu poder de repensar o mundo, suas heranças, perspectivas e códigos sociais em uma sociedade pósindustrial.

Por vezes desconcertantes e repetitivos, os discursos sobre a realidade de estarmos diante de avanços tecnológicos prodigiosos funcionam como parâmetros relevantes para justificarmos a presença de contínuos estudos dos desdobramentos decorrentes, como o fato da humanidade conviver com a produção de inúmeras mudanças sociais ao longo do tempo.

Tais mudanças alteram a potência de nossos sentidos (universo sensório) e a velocidade de nossos cálculos (universo racional), acrescentam novos elementos às nossas relações, um deles é não identificar uma relação óbvia e espontânea, entre a percepção do que se passa, e o usufruto dessas novas chances. Recorremos às chaves de leitura para compreender melhor tais transformações.

De Masi (2003) atesta que é preciso haver uma disposição cultural de cada indivíduo para reconhecer e apreciar as chances nas suas diversas dimensões, mas tal disposição é resultado de uma relação mútua entre indivíduo e seu contexto, o ambiente externo de vivências.

Um conjunto de sentimentos, emoções, opiniões em confronto com os meios de comunicação do entorno que ora adoça os indivíduos com a paz, ora os afoga em ansiedades.

Visto que a humanidade caminha nesse conjunto de capacidades sensoriais e racionais, por um lado, se inclinando de forma otimista, por outro, em desalinho e mesmo assim pronta para a superação de seus feitos contínuos; a mesma confirma a capacidade de igualmente recriar-se. De Masi (2003, p.16) afirma: “a vocação criativa é o menor denominador comum dos seres humanos".

Para esta pesquisa caminhamos nesse território, nesse "misterioso continente de espírito que é a criatividade humana", observando-a na prática, a associação de duas 


\section{Ensino, Saúde e Ambiente - V10 (2), pp. 79-106 Ago. 2017}

narrativas do conhecimento humano; Ciência e Arte, afinadas pelo potencial latente da criação.

Nesse sentido, é fundamental entender o alerta de estudiosos da área, dentre eles; Ostrower(1987), sobre armadilhas reducionistas que esvaziam o sentido da criatividade em qualquer atividade profissional, seja na Arte, seja na Ciência. Diz Ostrower (1987, p.38):

[...] processos de adestramento técnico, ignorando no indivíduo a sensibilidade e a inteligência espontânea do seu fazer. Isso, absolutamente, não corresponde ao ser criativo. [...] um químico poderá ser criativo na química porque formula suas perguntas em termos de química e não porventura em termos de alquimia. Entretanto, se esse químico nada mais vê pela frente do que química, se todos os seus interesses e também os conteúdos de vidas se resumem quase que exclusivamente em problemas de "especialista", especializações dentre especialidades, de fato, ele há de viver uma enorme redução enquanto potencialidade humana.

Dessa forma, conhecer o impacto de um conto de ficção científica, uma obra literária, junto ao público para discutir questões das ciências é a nossa posta em um caminho alternativo, quiçá criativo.Porque é preciso encontrar saídas para as situações inférteis do ensino de ciências reclamadas e descritas por diversos educadores (DE MEIS, 1998; ANDRADE, DOS ANJOS e RÔÇAS, 2009; FIGUEIRA-OLIVEIRA ET AL, 2012).

\section{Cada conto um ponto: ouvindo o que os alunos nos contaram}

Como resultado do encaminhamento do conto literário de FC, de uma página e meia e da ficha avaliativa onde os participantes foram convidados a liberar sua imaginação, produzindo uma continuidade ao final proposto pelo autor do conto. A solicitação foi que eles assumissem imaginar o passo seguinte em, no mínimo cinco linhas.

Participaram das oficinas ao todo 60 alunos, legendados aqui da seguinte forma: 21 alunos do ensino médio técnico em controle ambiental (A $\mathbf{E M T}$ ), 9 alunos de graduação em Produção Cultural( $\left.\mathbf{A}_{\mathbf{G}}\right), 17$ alunos de mestrado \&professores de ciências $\left(\mathbf{A}_{\mathbf{M}} \mathbf{P}\right), 13$ alunos de especialização em divulgação científica \& professores de ciências $\left(\mathbf{A}_{\mathbf{E}} \mathbf{P}\right)$.

Mediante a análise das oficinas realizadas ao longo do ano de 2016, compusemos quadros, que resumimos aqui em razão do formato desse artigo, com as falas dos participantes, segundo as duas principais categorias ou gêneros da narrativa de 


\title{
Ensino, Saúde e Ambiente - V10 (2), pp. 79-106 Ago. 2017
}

\author{
FC: utopia e distopia. Encontramos uma terceira categoria para falas que classificamos \\ como"alta subjetividade", de acordo com nossa linha de pensamento e proposta da \\ pesquisa.
}

\section{Quadro 4 - Como pensam os participantes das oficinas de ficção científica?}

\begin{tabular}{|c|c|c|c|}
\hline & Distopia & Utopia & Alta subjetividade \\
\hline EMT & $\begin{array}{l}A_{E M} \text { 19: Ao entrar no jardim, } \\
\text { Eva sente que algo ali estava } \\
\text { errado, inconformada com a } \\
\text { expressão do homem, Eva tenta } \\
\text { ajudá-lo a sair da depressão e } \\
\text { solidão, infelizmente Eva não } \\
\text { conseguiu, mas mesmo assim } \\
\text { Eva conta que estava } \\
\text { apaixonada por ele. Ao chegar } \\
\text { no local com sua ajuda, Eva } \\
\text { percebe um pânico no homem, } \\
\text { que desesperado mata o seu } \\
\text { ajudante. Eva o tranca } \\
\text { novamente no jardim deixando- } \\
\text { o em profunda solidão. } \\
\text { A } 20: \text { Ao entrar no jardim } \\
\text { Eva tenta conversar com o } \\
\text { homem, que se aproxima dela } \\
\text { com um gesto carinhoso e ao } \\
\text { perceber que Eva se arrependeu } \\
\text { e iria trancá-lo novamente, ele a } \\
\text { segura, a golpeia e a deixa } \\
\text { trancada em seu lugar e foge } \\
\text { com o intuito de procriar e } \\
\text { trazer sua espécie de volta. } \\
\text { A } 21: \text { Depois de um primeiro } \\
\text { contato com o homem, Eva } \\
\text { começa a se tornar amiga dele e } \\
\text { o ajuda a sair da jaula. Com } \\
\text { isso os dois passam a ser } \\
\text { perseguidos pelo governo } \\
\text { feminino. Apesar disso } \\
\text { conseguem conscientizar alguns } \\
\text { que o homem tem direito à } \\
\text { liberdade e derrubam a } \\
\text { presidente com um golpe de } \\
\text { Estado. Revoltada a presidente } \\
\text { se suicida. }\end{array}$ & $\begin{array}{l}A_{E M} \text { 3: Eva entra com o } \\
\text { sentimento estranho, um } \\
\text { sentimento que nunca teve } \\
\text { chamado, pena. Ela sentia pena } \\
\text { dele mesmo sabendo de tudo } \\
\text { que ele fizera, Eva acreditava } \\
\text { que o homem poderia melhorar. } \\
\text { Eva acreditava que através do } \\
\text { amor e a preocupação com o } \\
\text { próximo conseguiria mudar sua } \\
\text { cabeça e torná-lo uma pessoa } \\
\text { melhor. } \\
\text { AEM 5: Na verdade era tudo um } \\
\text { sonho de Eva Maria e ela } \\
\text { aprendeu a importância da } \\
\text { igualdade de gêneros, ela } \\
\text { preferiu o mundo em que vive. } \\
\text { A } \\
\text { angústia olhar de abandono, de } \\
\text { homem viu Eva. Ali surgiu um } \\
\text { olhar de esperança que, de que } \\
\text { daquelas poucas espécies que } \\
\text { sobraram poderiam nascer uma } \\
\text { noiva geração. E aquilo que } \\
\text { parecia ser o maior erro de sua } \\
\text { vida, tornou-se o maior acerto } \\
\text { de sua vida. Apesar de todos os } \\
\text { erros cometidos pela } \\
\text { humanidade, ainda tinha-se(sic) } \\
\text { esperança nessa espécie. }\end{array}$ & $\begin{array}{l}A_{E M} \text { 17: Eva entrou no jardim e } \\
\text { com a sensibilidade de uma } \\
\text { espécie mais avançada que o } \\
\text { nosso procurou criar uma } \\
\text { relação afetiva com o homem, } \\
\text { com isso, procriaram dando } \\
\text { origem a uma nova geração. } \\
\text { Uma geração diferente do que } \\
\text { nós, humanos, estamos } \\
\text { acostumados, as "pessoas", se } \\
\text { assim podemos chamar, não } \\
\text { interagem entre si, consideram- } \\
\text { se mais avançados que a } \\
\text { geração passada. A única forma } \\
\text { de comunicação entre a espécie, } \\
\text { é através de um objeto que entre } \\
\text { eles tem o nome de "celular", } \\
\text { seja lá o que isso for. } \\
\text { A }{ }_{\text {EM } 18: \text { Eva vai ao encontro do }} \\
\text { homem que quase não fala e } \\
\text { conta que ela entendeu o } \\
\text { desespero do seu olhar, pois éo } \\
\text { mesmo desespero que sentiu } \\
\text { quando tinha } 8 \text { anos,com isso } \\
\text { mostrando que ele não era o } \\
\text { único culpado dos eventos que } \\
\text { ocorreu no mundo. }\end{array}$ \\
\hline $\mathbf{G}$ & $\begin{array}{l}A_{G} 7: \text { Ao destrancar a gaiola, } \\
\text { Eva carrega consigo uma } \\
\text { seringa com seu último } \\
\text { medicamento composto pelos } \\
\text { exemplares de plantas do } \\
\text { museu. Este tinha como objetivo }\end{array}$ & $\begin{array}{l}A_{G} \text { 3: Enquanto caminhava em } \\
\text { direção a casa do homem, Eva } \\
\text { não conseguia parar de pensar } \\
\text { que o mesmo gene programado } \\
\text { nele para a destruição poderia } \\
\text { ser encontrado nas mulheres, de }\end{array}$ & $\begin{array}{l}A_{G} \text { 6: Seus passos pareciam } \\
\text { durara uma eternidade, ao } \\
\text { ritmo de seus batimentos } \\
\text { cardíacos.Seu corpo enviava } \\
\text { vários sinais de que aquela } \\
\text { decisão era incondicional, mas, }\end{array}$ \\
\hline
\end{tabular}




\section{Ensino, Saúde e Ambiente - V10 (2), pp. 79-106 Ago. 2017}

\begin{tabular}{|c|c|c|c|}
\hline & $\begin{array}{l}\text { alterar as células malignas de } \\
\text { um ser, tornando-o mais } \\
\text { sensivel ao ambiente em que } \\
\text { vive. Ao encontrá-lo, Eva tira a } \\
\text { seringa e introduz no homem, } \\
\text { fazendo-o de cobaia de seu } \\
\text { experimento. A partir dalí, Eva } \\
\text { nos anos seguintes, passa a ter a } \\
\text { rotina de dar todos os dias, uma } \\
\text { dose do medicamento ao } \\
\text { homem, analisando, } \\
\text { continuamente, } \quad \text { seu } \\
\text { desenvolvimento. Após sete } \\
\text { anos, o homem é encontrado } \\
\text { morto na varanda. Eva conclui } \\
\text { que, o homem sem um pouco de } \\
\text { maldade não sobrevive ao } \\
\text { mundo atual. } \\
\text { A } \text { g: Neste mesmo instante o } \\
\text { homem sobrepõe sua mão sobre } \\
\text { a de Eva que conduzia a sua em } \\
\text { direção ao seu rosto, ele } \\
\text { reconduz Eva em direção a } \\
\text { porta de entrada, Eva entende } \\
\text { que ele indica que ela saia; Eva } \\
\text { sai e volta a trancar a porta. Ao } \\
\text { retornar seu olhar para aquela } \\
\text { espécie Eva percebe que ele } \\
\text { chora e balbuciando diz: "tenho } \\
\text { medo, tenho medo". Eva } \\
\text { também chora e não consegue } \\
\text { entender o que de tão terrivel } \\
\text { eles um dia fizeram para } \\
\text { chegarem a esse ponto. }\end{array}$ & 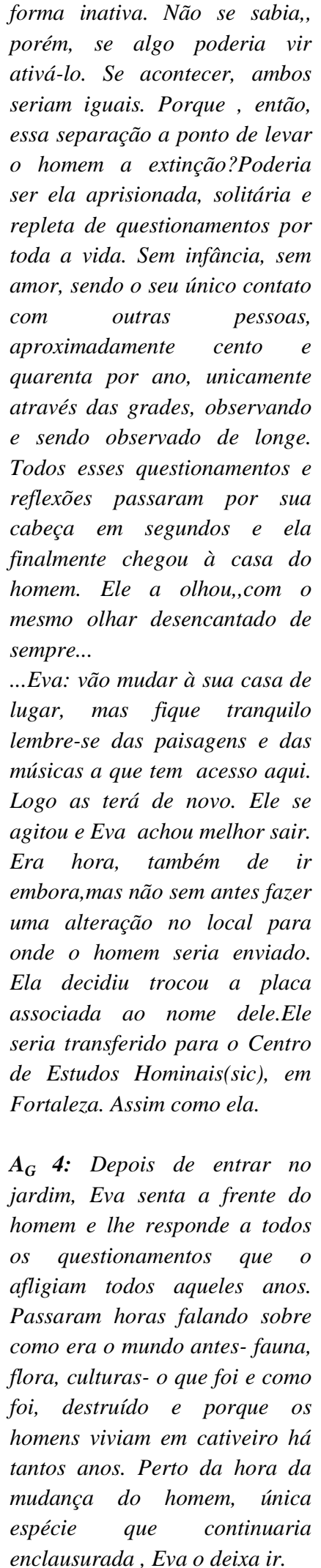 & $\begin{array}{l}\text { mesmo assim,ele se movia quase } \\
\text { que sozinho.Seus olhos se } \\
\text { encontraram. Eva já havia } \\
\text { olhado para eles antes, mas } \\
\text { dessa vez parecia a primeira } \\
\text { vez. } \\
\text { E então, dois corpos que nunca } \\
\text { estiveram tão próximos um do } \\
\text { outro, experimentavam pela } \\
\text { primeira vez um misto de } \\
\text { curiosidade, medo e certa } \\
\text { excitação. o que poderia } \\
\text { acontecer? Eva sabia que se } \\
\text { tratava de um ser que ficou } \\
\text { enjaulado sua vida inteira, } \\
\text { sabia que aquele primeiro } \\
\text { contato poderia ser } \\
\text { perigoso.Tratou-se de adotar } \\
\text { uma posição inofensiva ao } \\
\text { mesmo tempo que aproximava } \\
\text { com cautela. o homem, por } \\
\text { outro lado, ao perceber aquela } \\
\text { nova presença se aproximando } \\
\text { cada vez mais, reagiu como se } \\
\text { tivesse defrente à uma ameaça. }\end{array}$ \\
\hline $\mathbf{E}$ & $\begin{array}{l}A_{E} \text { P9: O homem se volta para } \\
\text { ela e como os olhos a convida } \\
\text { para sentar-se do seu lado. A } \\
\text { partir daquela proximidade Eva } \\
\text { entende toda a solidão } e\end{array}$ & $\begin{array}{l}A_{E} P 4: \text { O homem que quase não } \\
\text { falava e demonstrava no olhar } \\
\text { uma imensa solidão de um } \\
\text { sorriso quando vê Eva em sua } \\
\text { varanda. Eva contou a ele que }\end{array}$ & $\begin{array}{l}A_{E} P 2: \text { Ele sentindo-se } \\
\text { abandonado por aquela fagulha } \\
\text { de esperança no olhar de Eva } \\
\text { quase se enxerga como } \\
\text { semelhante na visão de uma }\end{array}$ \\
\hline
\end{tabular}




\section{Ensino, Saúde e Ambiente - V10 (2), pp. 79-106 Ago. 2017}

desamparo que ela antes observava no olhar do homem. A diretora, diante da situação decide manter Eva enclausurada com o homem.

$A_{E}$ P12: Eva se dera conta que o sentimento que a impulsionava a tomar tal atitude era a paixão que começou a sentir por aquele homem quando ainda era criança. Ao se aproximar do homem foi atacada pelo mesmo que fugiu deixando Eva para trás com seus últimos suspiros. sempre fora apaixonada e que queria reiniciar a espécie humana os dois fugiram e foram ter filho, viveram bem com perspectivas futuras não tão entediantes como uma perspectiva de reprodução a partir de um banco de DNA. Eva rompeu com barreiras sociais e foi viver a sua vida com ele tiveram quatro filhos, ela estava muito feliz $e$ realizada com a sua família. Um novo recomeço(sic).

$A_{E}$ P7: Imediatamente ele começa a tocá-la, apalpar e ela se desespera, teria errado ao pensar que a fragilidade que via nele não existia? E sua natureza de depredar o iria aflorar e com sua imensa violência iria acabar com ela?Nesse turbilhão de pensamentos ele a surpreendeu abraçando-a. Um abraço com uma imensa ternura. Um contato que ela nem sequer imaginava poder sentir. Como esse toque a fez ter sensações que não sabia existir. Coração acelerado, pernas trêmulas, mãos suando frio. Seria essa a sensação do medo no último instante de vida?

Não, Eva se recusa acreditar que aquele animal tão indefeso fosse capaz de destruí-la. A partir daquele instante Eva percebeu que ela sim estava trancada para sensações que nunca havia pensado existir e a porta aberta foi para seus sentimentos em pensar em novo destino para a humanidade, um novo recomeço, que pudesse haver um novo momento.

$A_{M}$ P9: Ao destrancar a porta Eva é prontamente jogada no chão pela força com que o homem abre a porta e fica desacordada. No dia seguinte, ela é acordada pela diretora do Parque e percebe que o homem tinha desaparecido.

AMP11: $O$ olhar do homem muda, se torna surpreso e até menina. E anseia por um futuro devorado pelo tempo que somente será alcançado pelo olhar da próxima observadora.

$A_{E}$ P5: Entra para finalizar em parte uma história, trazendo um aprendizado adquirido através dos vinte anos de convivência com objeto de pesquisa.

$A_{M}$ P6: $\quad$ Naquele momento
puderam sentir o corpo um do outro de uma maneira singular era uma sensação nova.Eva teve a certeza de que em sua vida faltava algo importante: o homem.

$A_{M}$ P1: Quando Eva se deparava com esse homem, o abraça,

demonstra uma afetividade que $A_{M}$ P10: Eva se depara com toda
$A_{M}$ P4: A angústia criada pelo último olhar trocado com o homem faz com que Eva tome uma atitude inesperada, ela decide dar liberdade ao homem;porque ele não teria direito a liberdade?Teria ele culpa pelos erros dos seus antepassados? 


\section{Ensino, Saúde e Ambiente - V10 (2), pp. 79-106 Ago. 2017}

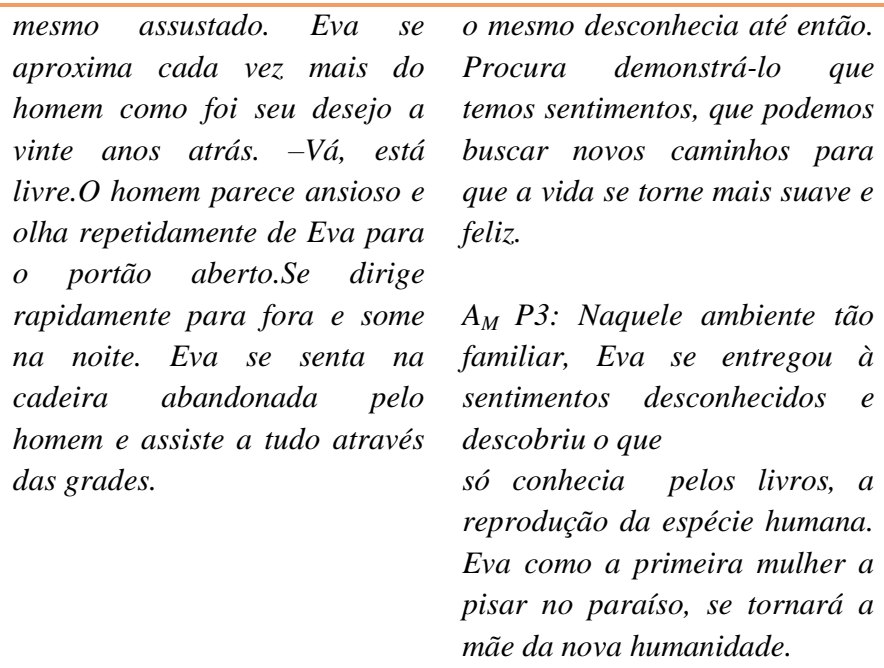

$A_{M}$ P3: Naquele ambiente tão

familiar, Eva se entregou à

sentimentos desconhecidos $e$

descobriu o que

só conhecia pelos livros, a

reprodução da espécie humana.

Eva como a primeira mulher a

pisar no paraíso, se tornará a

mãe da nova humanidade.

a situação triste observada,
porém não consegue se
expressar mediante o contexto e
em reverter o quadro, uma vez
que Eva era fruto de uma
clonagem humana e toda a
humanidade estava em extinção,
pois foram vítimas de uma
intensa crise mundial.
A P15: Com muito receio Eva
se permite aproximar-se do
humanoide e vê nele traços que
lhe são familiares, como se
entendesse a empatia em sua
plenitude. O homem de olhar
cansado convida Eva para
tentar se comunicar em vão.

tentar se comunicar em vão.

Pensar a sociedade a partir de um conto literário de FC é uma forma de eleger um produto a partir do qual a cultura reflete sobre si mesma. É uma forma de oferecer um espelho para revermos em que contextos nascem as ideias. Essa perspectiva consegue articular a análise crítica sobre a sociedade com a natural subjetividade existente. A FC nos oferece cenários distintos, por vezes utópicos ou distópicos. A utopia, intimamente ligada a era moderna, traz uma narrativa sobre a sociedade feliz e perfeita; ou ainda sob o sentido etimológico significa u-topos - o mesmo que lugar nenhum- também pode ser entendida como discurso político sobre como uma sociedade ideal e justa deveria ser. Uma espécie de condição de emancipação, confiança no sentido positivo estampam a potência desse olhar próprio ao século XVI, na obra de Thomas Morus autor do termo utopia (HILÁRIO, 2013). Já no século XX, onde despontou a distopia ou anti-utopia, o pensamento é completamente oposto. Etimologicamente, significa distorcida de lugar. O prefixo disé entendido como, anormal, mal-funcionamento, mal-estar, enquanto, topos significa o mesmo que lugar. A distopia parece estar em sincronia com as sociedades atuais dado ao grau de instabilidade de valores, circunstâncias e perspectivas.Esses dois paraísos artificiais ocupam espaço na literatura, no cinema, e em outras expressões artísticas proporcionando ao leitor, telespectador ou outro tipo de audiência o seu deslocamento no mundo dos sentidos e da imaginação por mais próximas que as obras se revelem.

Voltando nosso olhar para a análise dos resultados obtidos nas oficinas além de ser possível revelar o estágio do imaginário dos alunos que participaram, foi possível reconhecer a força dessas duas categorias, a utopia e a distopia presentes nos principais 


\section{Ensino, Saúde e Ambiente - V10 (2), pp. 79-106 Ago. 2017}

resultados. Esses lugares inventados para um encaminhamento posterior positivo ou negativo disparou pistas sobre como um conto literário de FC agiu no deflagrar uma série de pensamentos sobre as relações humanas.

Nesse estudo exploratório, ao analisarmos os textos produzidos pelos alunos envolvidos, percebemos uma marcante diferença de desenvoltura no que diz respeito aos níveis de ensino e a disposição em dar "asas à imaginação". Afinal, a nossa pergunta nesse artigo é,Como educar a imaginação para compreender Ciências?

Os alunos do ensino médio e de graduação foram ousados em deixar a imaginação fluir, tanto na forma escrita, como também na disposição da leitura em voz alta para os respectivos grupos após o momento de debate e impressões coletivas sobre o texto.

Segundo Root-Bernstein (2001), tanto a ciência quanto a arte são demonstrações do seguinte fato, interpretar com a imaginação para criar a compreensão. Estamos na primeira etapa desse esforço e pelo que foi possível perceber, os alunos ainda estão mais propensos essa entrega de seus universos sensórios.

Comparando a mesma proposta com alunos-professores do mestrado e especialização, encontramos um cenário mais conservador. Habituados com a rotina de decisão das atividades didáticas em sala de aula, os professores que participaram da oficina de literatura de ficção científica após uma aula temática sobre o tema, revelaram-se excessivamente cautelosos em deixar fluir a imaginação. As autoras ouviram comentários como: " acho que não consigo fazer isso", "muito difícil esse exercício", "nunca mais vou pedir aos meus alunos para escreverem em cinco linhas", sutis resistências apresentadas na oficina. Mais estáveis em suas convicções sobre o papel que devem desempenhar em uma sala de aula, ainda que circunstancialmente como alunos, mostraram-se mais relutantes a uma abordagem lúdica e culturalista, encaminhada por nós. As respostas foram breves e com pouco uso da fantasia. O debate posterior também não se estendeu como nos primeiros grupos, embora pudéssemos esperar questionamentos sobre os temas como: O que leva a extinção de uma espécie? Banco de DNA é possível? As espécies são geneticamente programadas para algo? Caso afirmativa essa questão, é certo natural essa programação realizar-se?

Todas questões postas no conto literário proposto na oficina como extrapolações do autor. O envolvimento controlado pode ser interpretado como uma autocensura, em função de uma tradição de abordagens de convencionais onde cada 


\section{Ensino, Saúde e Ambiente - V10 (2), pp. 79-106 Ago. 2017}

resposta será rigorosamente averiguada. Essas posturas persistiram ainda que ao partilharmos a ideia da oficina, tenhamos frisado a total liberdade para o pensamento. Tais resultados foram suficientes para o primeiro passo da pesquisa e acena por estratégias mais complexas e novas perguntas, um novo desafio, para conseguirmos uma adesão mais espontânea vinda de professores que passam por um aprimoramento profissional.

\section{Considerações finais}

O físico e matemático Freeman Dyson (1998, p.75) resume bem a relevância e atualidade de abordagem da ficção científica: “... é mais esclarecedora do que a Ciência para compreender como a tecnologia é vista por pessoas situadas fora da elite tecnológica. A Ciência proporciona o input técnico para tecnologia; a ficção científica nos exibe o output humano".

Se a investigação sobre o uso da FC em sala de aula não é novidade no mundo (DUBECK et al, 1990, 1993, 1998; DYSON, 1998; FREUNDENRICH, 2000), no Brasil identificamos ainda um campo fértil a ser mais explorado. Nos últimos anos, como reflexo do tipo de papel social ocupado pela Ciência e Tecnologia na vida das sociedades, alguns estudos marcam a inserção da FC nas esferas educacionais seja na composição de material didático, seja em diversificadas experimentações de linguagens, recursos, metodologias e outros meios de divulgação (GREF, 1993; DE LA ROCQUE e TEIXEIRA, 2001; PIASSI e PIETROCOLA, 2009; MENDONÇA, 2009; MACHADO, 2012).

A partir das análises realizadas, as autoras defendem que a FC, por meio da literatura, contribui para um ensino de ciências que considere o imaginário como terreno fértil para lidar com ideias científicas, a partir de caminhos prazerosos e criativos, os quais são pouco presentes nas salas de aula. O caminho de compreensão das oficinas teve início desde a seleção do público participante, passando pelo desenho dos objetivos - fundamentação teórica - até a leitura flutuante do material coletado, bem como as observações do ambiente de pesquisa e as falas dos participantes.

Em pauta esteve sempre a intencionalidade de fazer com que os participantes se deparassem com o inusitado (desequilíbrio cognitivo) e com uma situação-problema cuja saída se dava por meio da imaginação. Foi assim que as autoras escolheram um conto de ficção científica escrito por um autor brasileiro, onde estão contidos os dilemas 


\section{Ensino, Saúde e Ambiente - V10 (2), pp. 79-106 Ago. 2017}

do mundo contemporâneo, questões como, solidão, compaixão, conhecimento científico, gênero, relações sociais. É de Triviños (1987, p.42-43), a afirmação:

A ideia fundamental, básica da fenomenologia, é a noção de intencionalidade. Esta intencionalidade é a consciência que sempre está dirigida a um objeto. Isto tende a reconhecer o princípio que não existe objeto sem sujeito.

Diante de uma sociedade imersa na Ciência e na Tecnologia,caracterizada pelo que alguns estudiosos chamam de cultura-mundo, uma espécie de fenômeno totalizante apoderou-se dos indivíduos modificando, seus estilos de vida, seus pensamentos, enfim, seu conjunto de símbolos, por meio de uma primeira instância: seu imaginário. Elementos estruturantes das sociedades, o referido binômio impregnou a vida social, cultural e individual com o dogma do progresso, de otimismo tecnológico suscitando sonhos, inebriando subjetividades e a esperança de um futuro brilhante.

Porém, quando a confiança sobre a técnica se desgasta, quando os grandes dilemas emergem, as sociedades tomam conhecimento das grandes catástrofes ambientais, das ameaças de guerra nuclear, dos organismos geneticamente modificados e sinais que incidem sobre a saúde, bem como o outro lado dessa ideologia tecnológica, são acionados o alarme da incerteza, do medo, da morte, da exclusão, da onda de dessocialização, do enclausuramento provocado pelo high tech, enfim, do desequilíbrio de forças empreendidas para obtenção de sucesso (LIPOVETSKY E SERROY, 2011).

Nada mais humano do que, o ímpeto de desvendar cada vez mais o mundo a sua volta, a superação de si e a inquietação sobre como será o dia de amanhã. A história do conhecimento desde os primórdios, está centrada nesse processo de seus arranjos e rearranjos em um fluxo de descortinar permanentemente os contextos sociais que se apresentam.

Entendemos que frente às incertezas, e, às subjetividades invadidas contrapõese com bases culturais revitalizadas, herdadas das identidades coletivas como lentes que irão ampliar um movimento para além das fronteiras entre saberes.

Dentre as diversas lentes de aumento sobre a sociedade contemporânea, propomos a literatura, especialmente, na literatura de ficção científica, algumas pistas sobre como o conhecimento científico pode acessar novas gerações de alunos de todos os níveis. Se há um consenso sobre a influência da ciência e da tecnologia em nossa sociedade ocupando um espaço tão importante quanto o capital, o campo literário é parte desse cenário. 


\section{REFERÊNCIAS BIBLIOGRÁFICAS:}

ANDRADE, T.J.S.; ANJOS, M. B.;RÔÇAS,G.. A árvore na poesia de Drummond: a construção de livro paradidático para a Educação Ambiental. Ciência e Cognição, v.14, (3):103-113, Nov., 2009.

ATKIN, J. M. Applying Historic Lessons to Current Educational Reform, Symposium: Reflecting on Sputnik: Linking the Past, Present, and Future of Educational Reform, School of Education, Stanford University, Washington, DC, 4 out,1997.

BYBEE, R. W.Sputnik ERA: Why is this educational reform different from all other reforms?. Center for Science, Mathematics, and Engineering Education National Research Council, Symposium: Reflecting on Sputnik: Linking the Past, Present, and Future of Educational Reform, School of Education, Stanford University, Washington, DC, 4 out, 1997.

BARTHES,R..AULA INAUGURAL DA CADEIRA DE SEMIOLOGIA LITERÁRIA DE FRANÇA.7 de janeiro de 1977. Editora: Cultrix, São Paulo.

BAUMAN, Z. A Cultura no mundo líquido moderno. Rio de Janeiro: Zahar, 2013. BRONOWSKI, J. Arte e conhecimento, ver, imaginar,criar.São Paulo:Martins Fontes, 1983.

CAMILO, R. do E. S..Ficção Científica em sala de aula: investigação participativa do uso da linguagem de ficção científica como instrumento pedagógico. Nilópolis, RJ: IFRJ, 2014. Dissertação (Mestrado Profissional em Ensino de Ciências) - Programa de Pós-graduação em Ensino de Ciências, Instituto Federal de Educação, Ciência e Tecnologia do Rio de Janeiro. PROPEC, 2014

CARNEIRO , M. H. da S.; GASTAL, M. L. História e Filosofia das Ciências no Ensino de Biologia.Ciência e Educação, v.11, n.1,p. 33-39, 2005.

CASTRO, A. D. Ensino de Ciências: unindo a pesquisa e a prática.Prefácio.IN: ANA MARIA PESSOA DE CARVALHO,(Org.), São Paulo:Cengage Learning, 2015.

CORTAZAR, J. Valise de cronópio. Trad. Davi Arriguei Jr. e João Alexandre Barbosa,São Paulo: Perspectiva,1993.

DEBOER, E.G. What we have learned and where we are headed: lessons from the Sputnik Era. Colgate University, Symposium: Reflecting on Sputnik: Linking the Past, Present, and Future of Educational Reform, School of Education, Stanford University, Washington, DC, 4 out, 1997.

DÉCIO, J. A forma conto e a sua importância. Alfa:Revista de Linguística, v.22-23, 1976-1977. Disponível: http://seer.fclar.unesp.br/alfa/article/view/3585.Busca em 6 de dezembro de 2016.

DE MASI, D. Criatividade e grupos criativos/ Domenico de Masi.Rio de Janeiro: Sextante, 2003. 795 p.

DE MASI, D. Aemoção e a regra:grupos criativos na Europa de 1850 a 1950/ Domenico de Mais (Org.) $9^{a}$ Edição, Rio de Janeiro: José Olímpio, 2007,419. p.

DE MEIS, L. Ciência e educação-O conflito humano-tecnológico. Rio de Janeiro: Graftex Editora,1998, 198p.

DEWEY, J. Art as experience. Penguin Group: New York, 2005, 363p.

DUBECK, L. W. et. al. Science fiction aids science teaching. Phys. Teach., may 1990. p. 316- 319.

Sci-Fi in the classroom: making a "deep impact" on young people's interest in science. Mercury,nov./dec. 1998. p. 24-28.

Finding facts in science fiction films. Sci. Teach.,apr./1993. p. 47. 
DOW,P. Sputnik Revisited: historical perspectives on science reform.Symposium: Reflecting on Sputnik: Linking the Past, Present, and Future of Educational Reform,Washington, DC, 4 out, 1997.

DUREAU, Y..Utopieetcinèma. Paris: CorleteditiónsDifusión, 2005.

DYSON, F.J..Mundos Imaginados: conferências Jerusalém-Harvard/Freeman Dyson:Tradução Claudio Weber Abramo - São Paulo:Companhia das Letras, 1998.

FLEURY, M.T.L.; MATTOS, M. I. L.de. Sistemas educacionais comparados. Estud. av., São Paulo, v. 5, n. 12, p. 69-89, Aug. 1991

FREUDENRICH, C. C. Sci-fi science: using science fiction to set context for learning science. The Science Teacher, v. 67, n. 8, nov.2000. p. 42-45.

FIGUEIRA-OLIVEIRA, D. et al.Construção de Espaços de escuta, diagnóstico e análise coletiva de problemas de saúde pública com a linguagem teatral: o caso das oficinas de jogos teatrais sobre a dengue. Interface - Comunic.,Saúde, Educ., v.16, n.43, p. 929-41, out/dez, 2012.

FIGUEIRA-OLIVEIRA, D..Estudo das convergências em pesquisa e ensino de ciência e arte a partir da análise documental e metodológica. Rio de Janeiro: 2012. Doutorado (Tese do Programa de Pós-Graduação em Ensino de Biociências e SaúdeInstituto Oswaldo Cruz-Fundação Oswaldo Cruz - Rio de Janeiro).

FOUREZ, G. Crise no Ensino de ciências?Investigações em Ensino deciências.v,8,(2), 2003.109-123p.

GARCIA, P.S.; FAZIO, X.; PANIZZON, D.. Formação inicial de professores de ciências na austrália, brasil e canadá: uma análise exploratória.Ciênc. educ. (Bauru), Bauru, v. 17, n. 1,p. 1-19, 2011.

GOTLIB, N.B.Teoria do Conto. Editora: Ática, 2004.

GREF - Grupode Reelaboração do Ensino de Física. Física3:Eletromagnetismo.São Paulo, Ed. da Universidade de São Paulo, 1993.

GREENE, M. Releasing the imagination: Essays on Education, the Arts, and Social Change.Editora: JosseyBass (EUA), 1995.

HILÁRIO, L. C..Teoria crítica e literatura: a distopia como ferramenta de análise radical da modernidade.Anu.Lit., Florianópolis,vol.18,n.2,p.201-215, 2013.

HUXLEY, A. Admirável mundo novo.Tradução Lino Vallandro e Vidal Serrano.São Paulo: Globo, 2001.

KRASILCHIK, M. Reformas e realidade: o caso do Ensino de ciências. In:São Paulo em Perspectiva, 14(1) 2000, p.85-93.

LA ROCQUE, L.R;TEIXEIRA,L.A. Frankenstein, de Mary Shelley e Drácula de BramStocker: gênero e ciência na literatura.Histórias, Ciências, Saúde Manguinhos,v.3(1),10-34, mar-jun, 2001.

LE GUIN, U. K..A mão esquerda da escuridão.2 $2^{a}$ edição. São Paulo: Aleph 2008.

LIPOVESKY,G; SERROY, J. (2011). A cultura-mundo: resposta a uma sociedade desorientada/Gilles Lipovetsky e Jean Serroy -São Paulo: Companhia das Letras, 2011, 207p.

MACHADO, C. A.. Ficção científica: utopia ou distopia? Felicidade, angústia e prazer na pós-modernidade. Comunicação e Educação, ano 18, n.1, jan-jun, 2013.

MATTHEWS, M. R. .História, Filosofia e Ensino de Ciências: a tendência atual de reaproximação.Cad. Cat.Ens.Fís.,v.12,n.3, dez,1995, p.164-214.

MENDONÇA, L.G. A literatura de ficção-científica como estratégia de ensino: discussão da ética profissional e do saber-fazer da ciência em sala de aula. Revista Ciências\&Ideias, Nilópolis, n. 1,v. 1, out-mar, p: 41-51. 2009-2010. 
NASCIMENTO, L. A. e; RÔÇAS, G.. O nó da avaliação em ciências: formando, deformando ou conformando?Revista Brasileira de Ensino de Ciência e Tecnologia,v. 9, n. 1, 2016.

OSTROWER, F. Criatividade e processos de criação/FaygaOstrowerPetrópolis:Vozes, 1987,187p.

PIASSI, L.; PIETROCOLA,M. Ficção científica no ensino de física:utilizando um romance para desenvolver conceitos. XVI SIMPÓSIO NACIONAL DE ENSINO DE FÍSICA, 2003.

PIASSI, L.; PIETROCOLA, M. De olho no futuro:ficção científica para debater questões sociopolíticas de ciência e tecnologia em sala de aula.Ciência \& Ensino,v.1, número especial, nov, 2007.

PIASSI, L.; PIETROCOLA, M. Ficção científica e ensino de ciências: para além do método de 'encontrar erros em filmes'. Educação e Pesquisa, São Paulo, v.35, n.3, set/dez., 2009, p.525-540.

PIETROCOLA, M.. Curiosidade e Imaginação: os caminhos do conhecimento nas ciências, nas artes e no ensino. IN: ENSINO DE CIÊNCIAS : UNINDO A PESQUISA E A PRÁTICA.(Org): ANNA MARIA PESSOA DE CARVALHO. São Paulo: Cengage Learnig, 2015.

RABKIN, E. The fantastic in literature. New Jersey: Princeton University, 1977.

READ.H.A educação pela arte.São Paulo: Martins Fontes, 2001,366p.

RODRIGUES, A.T. Sociologia da Educação, DP e A Editora, 2003, 160p.

ROOT-BERNSTEIN, R. e ROOT-BERNSTEIN, M..Centelha de gênios: como pensam as pessoas mais criativas do mundo/Robert e Michele Root-Bernstein. São Paulo: Nobel, 2001,332p.

RUTHERFORD, J. F. Sputnik and Science Education. American Association for the Advancement of Science. Symposium: Reflecting on Sputnik: Linking the Past, Present, and Future of Educational Reform,Washington, DC, 4 out,1997.

SIMON,L.C.S..O conto e o Pós-modernismo: recorte, velocidade e intensidade. Revista Investigações, v. 20, n.1, 2007, p.127-148.

SNYDERS, Georges. Alunos felizes: reflexão sobre a alegria na escola a partir de textos literários. São Paulo: Paz e Terra.1993.

TRIVIÑOS, A.N.S. Introdução à pesquisa em ciências sociais: a pesquisa qualitativa em educação/Augusto Nibaldo Silva Triviños.- São Paulo:Atlas, 1987.

VASSILIOU, A. Teaching Reading in Europe: contexts, policies and practices. Education, Audiovisual and Culture Executive Agency, 2011.

VAZ, J.P. Ah... Insensato Coração. IN:FCdoB: Panorama2008/2009/ vários autoresSão Paulo: tarja, Editorial, 2011, p. 211-214.

WARD, H. et al. Ensino de Ciências. Porto Alegre: Artmed, 2010.

ZANETIC, J. Física e literatura: construindo uma ponte entre as duas culturas.História, Ciências, Saúde - Manguinhos, v. 13 (suplemento), outubro, 2006, p. 55-70. 